Отримано: 10 квітня 2018 р.

Прорецеензовано: 16 квітня 2018 р.

Прийнято до друку: 27 квітня 2018 p.

e-mail: michaladam.lesniewski@wp.pl

DOI: $10.25264 / 2311-5149-2018-9(37)-59-64$
Leśniewski M. A. Competitiveness as a measure of organization development - the theoretical study. Наукові записки Національного університету «Острозька академія». Серія «Економіка» : науковий журнал. Острог : Вид-во НаУОА, червень 2018. № 9(37). С. 59-64.

Michał Adam Leśniewski, Ph. D.

Institute of Management Jan Kochanowski University in Kielce

\title{
COMPETITIVENESS AS A MEASURE OF ORGANIZATION DEVELOPMENT - THE THEORETICAL STUDY
}

Competitiveness is both the functioning basis and the measure of the organization development which is subjected to the laws of the market. The study presents the general look at the problem of competitiveness. The aim of the research is to present the competitiveness as the measure of the enterprise development. The following research hypothesis was taken in the study: competitiveness is an abstract term which is the basis for the enterprise's functioning on the competitive market. The method of literature interpretation was applied in the study, in terms of which the logical reasoning (logical thought) and perception were used. This elaboration confirms the competitiveness importance for the organization's functioning in the changing environment.

Key words: competitiveness, the measure of organization development, types of competitiveness.

\section{Лсшнєвський Міхал Адам, \\ доктор філософії, Інститут управління \\ КОНКУРЕНТОСПРОМОЖНІСТЬ
ЯК ПОКАЗНИК РОЗВИТКУ ОРГАНІЗЦЇ̈ - ТЕОРЕТИЧНЕ ДОСЛІДЖЕННЯ}

Конкурентоспроможність є основою функиіонування, а також показником розвитку організації, який відображається в законах функціонування ринку. Дослідження представляє загальний огляд проблеми конкурентоспроможності. Наступна дослідницька гіпотеза була сформульована в дослідженні: конкурентоспроможність $\epsilon$ абстрактним явищем, який є основою функціонування підприємства на конкурентному ринку. У дослідженні використовували метод інтерпретації наукової літератури, у межах якого застосовували логічні міркування (логічний роздум) та сприйняття. Дослідження є підтвердженням важливості конкурентоспроможності для організації, яка функиіонує у змінному середовищі.

Ключові слова: конкурентоспроможність, показник організаційного розвитку, типи конкурентоспроможності.

\section{Introduction}

There are as many elaborations on the subject of competitiveness as there is no unified definition of competitiveness, which is the basis of the existence of an organization on the marketwhile maintaining a market economy (openly competitive). Competitiveness derives initially from the term of competition, whereas the competitive advantage results from the competitiveness. It may be stated that competitiveness cannot exist without competition just like the competitive advantage cannot exist without competitiveness. The relationships between competition, competitiveness and competitive advantage create a so called triad of the organization development. There is as much competitiveness as there are organisations (enterprises) ${ }^{1}$. Each organisation has a different view on the problem of the competitiveness.It can be argued that competitiveness is the individual approach of factors forming the organization.

The aim of the elaboration is to present the competitiveness as the measure of enterprise development. The following research hypothesis was adapted in this study: competitiveness is an abstract term which is the basis of the functioning of an enterprise on the competitive market. The method of literature interpretation was applied in the study, in terms of which the logical reasoning (logical thought) and perception were used. The interpretation method of the literature of the subject enables, inter alia, the presentation of the author's point of view, in other words, his own opinion and a certain belief on the research problem.

\footnotetext{
${ }^{1}$ Organization andenterprise are two terms used interchangeably in order to avoid excessive repetition. Competitiveness is not just a problem for enterprises, but also other organizations subjected to the laws of the free market including, e.g. municipalities, districts or regions or other organizations.
} 


\section{Competitiveness - introduction to the problem}

The substantive sense of the meaning of the competition comes down to rivalry between rivals. This competition may be seen both as a rivalry and cooperation. Competition as the rivalry means that the victory and defeat exist between the rivals (the better wins, the worse loses), however, the competition as the cooperation signifies the existence ofcommon sharing of profits and losses resulting from the market behavior of rivals. We deal with the phenomenon existing in this sense in many areas of political, economic, artistic, sports and cultural life as well as is social life (Koźmiński, 1999, p. 13-14).Competitiveness as the subject of interest of organizations, including enterprises, derives from the competition and contributes to the achievement of competitive advantage. The competitiveness receives the main impulsefrom the competition, which means from a certain state as well as a process taking place between the participants of the market. Finally, competitiveness allows the organizations to achieve competitive advantage.

The term «competition» is inextricably linked with the term «competitiveness». Competitiveness as the ability of the operator to competing is a relative and ambiguous term, which is mentioned by J. Brodawska-Szewczuk (Brodowska-Szewczuk, 2009, p. 87). Apart from that,despite the fact that it is a term often used, inter alia, in economy or management, it does not have a univocal definition. It is therefore included to so called abstract names, theoretical terms, which according to $\mathrm{M}$. Gorynia does not have designata possible to define directly (Gorynia, Jankowska, 2008, p. 51). For that reason, in his view competitiveness is the ability to compete, in other words, to act and survive in a competitive environment (Gorynia, 2002, p. 48). This terms is similarly defined by J.Burnewicz, according to whom the competitivenessis basically the ability to resist competition (Olczyk, 2008, s. 49).

A slightly wider explanation of this term is given by C. Hampden-Turner and A. Trompenaars, who notice that competitiveness of the enterprises is the rivalry and cooperation which lead simultaneously to learning essential technology, needs and requirements of customers (Hampden-Turner, Trompenaars, 2000, p. 121-122).

To sum up, it can be said that competitiveness is a process in which the participants of the market try to present a more beneficial offer of price, quality or other features affecting the decision of transaction, while pursuing their interests (Cyrkon, 2000, p. 35).

In order to talk about competition one needs to emphasize the fact that on a given market there must be at least two economic operators of identical or similar profile of supplying goods on the market. Only then canyou analyze the competitiveness of one in comparison to the other (Adamkiewicz-Drwiłło, 2010, p. 68).

According to S. Lachiewicz, competitiveness in modern reality of global economy is one of the most important indicators of the assessment of enterprise's functioning on the market. It is a kind of determinant of its development(Lachiewicz, Matejun, 2009, p. 98).

Competitiveness may have a certain set of features, assigned beforehand, which present it as a phenomenon which is relative, denoting quality, and which has clearly specified area of competitive contest. Competitiveness on the micro level is connected with the costs and the quality of the offered goods. Both the costs and the quality have the influence of the appropriate level of efficiency and profitability of sold goods and services, which in turn determine the participation of an enterprise on the market. Micro competition is defined as the ability of an enterprise to cope with the competition of other operators, to maintain and extend the market shares as well as to achieve, in connection with that, adequate profits(Olczyk, 2008, p. 14). Meso-competition is the ability to design and sell goods of a given field, branch or department, whose price, quality and other values are more attractive than adequate features of the goods offered by the competitors (Adamkiewicz-Driwiłło, 2002, p.128). The definitions of macro-competition determine it as the capacity to cope with the international competition and to maintain the high pace of demand without worsening the current account, whereas it is expressed on the international market as the acceptance of manufactured products of a given country and the increase of its shares on the export markets (Wysokińska, 2001, p. 37).

Taking everything into account, the conceptualizations of competition and competitiveness mentioned before, despite certain differences between the definitions, treat them as a very important element which decides on the success or failure of an enterprise, both on the local, international or global market.

\section{Classification and types of competitiveness}

In the literature of the subject, as evident from the above considerations, there is a multitude of various attitudes towards the concept of competition and competitiveness. As in the case of the definition, also when it comes to the types,one can talk about several criteria classifying them.

The criterion of actions or effects extracts the factorial competitiveness which shows predispositions of an enterprise to activities which form the foundations of their effective competing and the competitiveness of the results (Lubiński, Michalski, Misala, 1995, p. 9-13) exposing mainly the results of this competition.

According to a further criterion - evaluation interval - there is operative competitiveness and systematic competitiveness (Adamkiewicz-Drwiłło, 2010, p. 112). Operative competitiveness refers to the «inside» of a 
given operator, whereas the systematic competitiveness is connected with, inter alia, providing and intensifying the values and innovation of the processes used in an enterprise.

J. Brodawska-Szewczuk, who was mentioned before, distinguished the following types of competitiveness while analyzing its areas (Brodowska-Szewczuk, 2009, p. 90):

1) the real-resulting competitiveness of enterprises;

2) the competitiveness of resources and abilities of enterprises;

3) the competitiveness of the enterprise determined by customers;

4) the competitiveness of the production factors of a given country and region,the competitiveness of the functioning system of economy(the level of economic freedom).

It is worth noting that all of the above types are related to each other through cause and effect relationships.

Competitiveness may also be classified on the basis of the criterion of the moment of the assessment of the competitiveness. According to this criterion one may indicate the ex post competitiveness - in other words, the one already achieved by the operator, and the ex ante competitiveness - which means the one that the operator may or plans to achieve in the future (Gorynia,1996, p. 89).

Another division of criteria of side of market relations enables the distinction of competitiveness of a given operator based on «entries» from the competitiveness based on «exits». Using the criterion of observation time, can, however, point to the static competitiveness and dynamic competitiveness (Stankiewicz, 2002, p. 38-39).

The term of competitiveness (Leśniewski, 2015)may also be referred to the supply side and demand side. By the competitiveness of the supply side one should understand any procedures of the representatives of supply in order to acquire the representatives of demand side, so that they are inclined to allocate their orders with given producers of goods or services. Competitiveness of demand is approached from the other side: these are the representatives of the demand who compete with each other for the attention of the representatives of the supply. It is a characteristic situation when there is the surplus of the demand in comparison to the supply (Gorynia, Jankowska, 2008, p. 53). Within this same criterion, we can emphasize the competitiveness within the industry and the inter-branch competitiveness.

\section{Factors determining the competitiveness of the operators}

The level of the competitiveness of the enterprises and the organisations in general ismultifactorial conditioned. This issue is widely recognized by M. J. Stankiewicz, according to whom the competitiveness should be considered as a system created with four basic elements: potential of competitiveness, competitive advantage, instruments of competing and competitive position (Stankiewicz, 2006, p. 79). In the opinion of M. J. Stankiewicz it is the whole of material and immaterial resourcesof a given enterprise. It is also a resource of key and important for him competences and abilities, thanks to which the company may gain durable competitive advantageover other operators of a given sector (Stankiewicz, 2006, p. 79). Speaking of this element, it is worth mentioning the conceptualization of M. Gorynia who distinguishes two its meanings: narrow and broad. In the first one, the potential of competitiveness is treated as all the resources used or possible to use by an enterprise (Gorynia, 2002, p. 93). In the broader meaning, the term includes particularly the culture of an enterprise, its resources, organizational structure, strategic vision, as well as the process of creating the strategy. According to E. Skawińska, this potential includes in turn the human capital, physical and financial resources, invisible resources and organizational resources (Skawińska, 2002, p. 65).

The second of the elements mentioned by M. J. Stankiewicz, the competitive advantage, is understood as the effect of an efficient usage of the configuration of the components of the potential of the competitiveness, which enable the enterprise to generate an attractive market offer and the effectual instruments of competing (Stankiewicz, 2006, p. 80). According to K. Obłój, there are four basic advantages: natural position, the relation between the price and the quality, the service system increasing the costs of conversion and the service system building high entry barriers (Obłój, 2002, p. 104). Therefore, it is possible to say that an enterprise holds the advantage over the rivals when, by using possessed resources, it is able to provide a given market with an offer which will be chosen by the purchaser.

The oldest concept of competitive advantage is the concept of M. E. Porter. It postulates the search of the source of this advantage in the structure of the sector. The model of so called «Five strengths of competition» created by Porter is based on the statement that, apart from its structure, there are four outside strengths which affect the character and the intensity of competition in the sector and these include: bargaining power of the buyers, bargaining power of the suppliers, the threat of the emergence of substitutes and the threat of the emergence of new competitors. All the strengths presented on illustration 7 determine the intensity of the competition in a given branch as well as its profitability. The intensity of the activity of these strengths is equal in individual branches and it may convert into the measure of their development (Brodowska-Szewczuk, 2009, p. 87-100). The relation between the factors mentioned above defines the intensity of the competition inside the sector and its profitability.

Another factor, the instruments of competing, refers to the conscious and intentional usage of tools and methods of building the capital as well as of creating the value of the company (Stankiewicz, 2006, p. 80).The 
examples of such tools may include: the quality of the products, the range of assortment, company's image or the flexibility inadapting to the needs of the customers.

The competitive position is seen as the result of the enterprise's competition in a given sector, whereas this result is based on the comparison with the results of other operators from the same industry. The competitive position, as noticed by M. J. Stankiewicz, is a place on the scale of economic and non-economic benefits, which are provided by a given enterprise to the stakeholders, in comparison to the places taken by the competitors (Stankiewicz, 2006, p. 80). A reflection of the competitive position of a business entity is its competitive advantage.

These factors are the basis for measures aimed at achieving competitiveness in the future. This approach also indicates a set of factors that determine the competitiveness and measures for its assessment.

\section{External and internal factors conditioning the competitiveness}

The competitiveness of enterprises is conditioned by many different factors, which to a greater or lesser extent determine their position on the market. The key determinants of competitiveness of modern enterprises are of interactive nature, as noticed by W. Walczak, as they are a combination of interrelated factors, which create a multidimensional space (Walczak, 2010, p. 5). Therefore, these factors should not be seen as individual, isolated variables, but as a set of interpenetrating and interdependent elements occurring in the same time horizon. Factors determining competitiveness, as mentioned before, are highly diversified and therefore we can divide them into external factors and internal factors.

\subsection{External factors of competitiveness}

Gaining competitive advantage by an enterprise is inextricably linked to its environment, in other words the external factors forming the environment of functioning of the company, affecting or potentially affecting the activity of an enterprise. Both the dynamics and the potential define the conditions of functioning of a company. The environmentof the enterprise is, therefore, to be treated as the external determinants of the competitiveness which the enterprise has no influence on or it is to some extent limited. The environment of the enterprise is to be understood as the sum of constantly changing factors and processes which it is forced to cooperate with. For in the market surroundings there are forces which affect directly or indirectly the aims, the structure, the plans of procedure, the operations and the results of an enterprise (Porter, 1998, p. 23-24).

In general, it is assumed that the environment of the enterprise refers to the closer and further environment, which is noticed by S. Sudoł (Sudoł, 2002, s. 58).

The closer environment includes all the systems which the enterprise remains in direct relations with, such as the market or contractors. Whereas the further environment is called the macro-environment and it presents the systems which the enterprise has indirect relations with. Macro-environment is a set of conditions of functioning of an enterprise resulting from the fact that it functions in a given country and region, in a given climatic zone, in a given political, legal or system arrangement, etc. (Gierszewska, Romanowska, 2002, p. 32). The components of the macro-environment affect strongly the enterprise, however, as mentioned before, the enterprise is not able to change these conditions. These components are seen as the stimulants or threats. Whereas, the competitive environment includes all economic entities and individuals that havecooperative or competitive business ties with the enterprise. These include: suppliers, customers, as well as present and potentials competitors. Between these elements and the enterprise there is a feedback: the operators of the competitive environment affect the enterprise, and the enterprise affects these operators. Mutual relations, therefore, may be created efficiently. That is why, the possibility of an enterprise to have influence on the competitive environment, and therefore to improve one's own competitive position, is an extremely important element of the enterprise's strategy.

\subsection{Internal factors of competitiveness}

The internal determinants of competitiveness of the enterprises are directly connected with the decisions taken in the enterprise, such as: the choice of management system or organization system, the choice of marketing strategy, technology of production, cooperators or defining of the assortment. The determinants of competitiveness depending from the enterprise mainly include: the nature of the possession of the enterprise, the system of organisation and management and the production extent and costs. The key role is also played by the degree of involvement in public relations, which plays an important role in the enterprise as it affects its image and good opinion, mainly among the purchasers, which is reflected in the growth of their trust and willingness to make a purchase, and therefore, as noticed by A. Mitekand I. Miciuła, in the growth of the level of competitiveness of the enterprise (Mitek, Miciuła, 2010, p. 345-347). The level of employees' qualifications also has the key meaning among the internal factors. The role of the employees in shaping the competitiveness of the company is obviously important. Their potential as well as the knowledge and the abilities cause the fact that they are able to stay on the market, as well as to develop and gain new markets, using two different tools. Summing up, it may be said that a group of internal factors is identified with the resources owned by the enterprise and with the ability to use them in order to take more effective actions. The competitiveness of the enterprise is a derivative of the ability to use the possessed resources in the processes of acquiring the capital of clients and creating intellectual 
capital. Therefore, it should be understood as the result of multifaceted conditioning, dependencies and activities taken by the enterprise (Walczak, 2010, p. 5).

M. Krawczyk pays attention to similar internal conditioning, which include, inter alia, innovation and technological advancement, the culture of the enterprise, the way of financing its activity,the distribution chain, the price of the products and services as well as their quality, the abilities of the employees, own investments as well as the possibility to acquire capital (Krawczyk, 2012, p. 345).

Comprehensive approach to the factors affecting the competitiveness of enterprises was compiled by W. Walczak, who indicated in detail both the external and internal factors.In his model he paid particular attention to a certain group of factors which was less noticeable but it plays a key role in shaping the market competition. The role of these factors, according to W. Walczak, is not to be overestimated. These factors include, inter alia, unfair competition, arrangements, as well as business links, unfairly carried out tenders, connections, thanks to which the company obtains financial benefits by increasing their competitiveness in a given market. The above-mentioned factors W. Walczak called as the «outstanding» capacity in terms of forming business relationships with selected stakeholders, having appropriate permissions, in particular on the issue of administrative decisions and disposing of financial resources.

\section{Summary}

Competitiveness is an important link in the development of organization (enterprise) resulting from the competition and contributing to the competitive advantage. Competitiveness is the variety of the factors which form the organization. The development is a wide problem, which the competitiveness - which may be treated as the measure of organization's success ${ }^{2}$ - falls within.Eachorganization is responsible for the formation of its own competitiveness. The competitiveness should be seen through the prism of the internal and external factors of the organization, as well as the integrated factors, meaning internal and external (external and internal). Only the integrated view gives a full picture of these factors, which contribute to the achievement of the competitive advantage. The managers, as people who realize the process of organization management, have the obligation to shape the competitiveness. A manager in the partnership with his subordinates strengthen the competitiveness of the enterprise in a comprehensive way. The manager responsible forthe competitiveness may be described as a competition manager. The quality of the factors of competitiveness depends from the quality of the manager, in other words, from the level of his commitment to work together with his intellectual capital (knowledge, abilities, experiences, positive attitude towards work and people, etc.).

The conducted study of the literature along with the applied testing method confirms positively accepted research hypothesis, which takes the form of a thesis which sounds: competitiveness is an abstract concept which forms the basis of the functioning of the enterprise on a competitive market. Competitiveness must be shaped permanently, because the passage of time puts pressure on the factors of competitiveness, what is the competitiveness today, in the future ceases to be the basis for creating competitiveness.

The following study is another step in highlighting the importance of competitiveness in shaping the direction of achieving a competitive advantage. The quality of competitiveness is the quality of the competitive advantage.

\section{Bibliography:}

1. Adamkiewicz-Driwiłło H., Uwarunkowania konkurencyjności przedsiębiorstw, PWN, Warszawa 2002.

2. Adamkiewicz-Drwiłło H., Konkurencyjność przedsiębiorstw w świetle uwarunkowań współczesnej gospodarki, Wydawnictwo Dom Organizatora, Torun, 2010.

3. Brodowska-Szewczuk J., Konkurencyjność przedsiębiorstw i źródła przewagi konkurencyjnej, Zeszyty Naukowe, Seria: Administracja i Zarządzanie 2009, nr 80, s. 87.

4. Cyrkon E., Kompendium wiedzy o gospodarce, Wydawnictwo Naukowe PWN, Warszawa-Poznań, 2000.

5. Gorynia M., Koncepcja i metodyka badania konkurencyjności przedsiębiorstwa [w:] Konkurencyjność gospodarki Polski w dobie integracji z Unią Europejską i globalizacji, Materiały dodatkowe, SGH, Warszawa Grupa Lizbońska, 1996, Granice konkurencji, Poltext, Warszawa.

6. Gorynia M., Schemat analityczny luki konkurencyjnej - zarys [w:] Luka konkurencyjna na poziomi przedsiębiorstwa a przystąpienie Polski do Unii Europejskiej, Wydawnictwo AE, Poznań, 2002.

7. Gorynia M., Jankowska B., Klastry a międzynarodowa konkurencyjność i internacjonalizacja przedsiębiorstwa, Difin, Warszawa, 2008.

8. Gierszewska G., Romanowska M., Analiza strategiczna przedsiębiorstwa, PWE, Warszawa, 2002.

9. Hampden-Turner Ch., Trompenaars A., Siedem kultur kapitalizmu, Dom Wydawniczy ABC, Kraków, 2000.

10. Koźmiński A., Zarządzanie międzynarodowe, PWE, Warszawa, 1999.

11. Krawczyk M., Konkurencyjność przedsiębiorstw w świetle uwarunkowań ekologicznych, Studia i Prace Wydziału Nauk Ekonomicznych i Zarządzania nr 25, 2012.

\footnotetext{
${ }^{2}$ One should keep in mind that competitiveness can not only contribute to success, but also to the failure of the organization. Many studies treat competitiveness in terms of success and as such it is the subject of this study.
} 
12. Lachiewicz S., Matejun M., (red.), Konkurencyjność jako determinanta rozwoju przedsiębiorstwa, Wydawnictwo Politechniki Łódzkiej, Łódź, 2009.

13. Leśniewski M. A., Konkurencyjność miękka przedsiębiorstw, Warszawa, 2015.

14. Lubiński M., Michalski T., Misala J., Międzynarodowa konkurencyjność gospodarki. Pojęcia i sposób mierzenia, Instytut Rozwoju i Studiów Strategicznych, Warszawa, 1995.

15. Mitek A., Miciuła I., Współczesne determinanty rozwoju przedsiębiorstw prywatnych, Studia i prace Wydziału Nauk Ekonomicznych i Zarządzania nr 28, Uniwersytet Szczeciński, 2010. 2002.

16. Obłój K., Tworzywo skutecznych strategii. Na styku starych i nowych reguł konkurencji, PWE, Warszawa,

17. Olczyk M., Konkurencyjność: teoria i praktyka: na przykładzie polskiego eksportu artykułów przemysłowych na unijny rynek w latach 1995-2006, CeDeWu, Warszawa, 2008.

18. Porter M. E., Strategia konkurencji, PWE, Warszawa, 1998.

Stankiewicz M. J., Konkurencyjność przedsiębiorstwa. Budowanie konkurencyjności przedsiębiorstwa w warunkach globalizacji, Towarzystwo Naukowe Organizacji i Kierownictwa «Dom Organizatora», Toruń, 2002.

19. Stankiewicz M. J., (red.), Zarządzanie wiedzą jako kluczowy czynnik międzynarodowej konkurencyjności przedsiębiorstwa, Wydawnictwo TNOiK «Dom Organizatora», Toruń, 2006.

20. Skawińska E., Konkurencyjność przedsiębiorstw-nowe podejście, PWN, Warszawa-Poznań, 2002.

21. Sudoł S., Przedsiębiorstwo. Podstawy nauki o przedsiębiorstwie. Teorie i praktyka zarządzania, Wydawnictwo «Dom Organizatora», Toruń, 2002.

22. Walczak W., Analiza czynników wpływających na konkurencyjność przedsiębiorstw «E-mentor» nr 5 (37), 2010 .

23. Wysokińska Z., Konkurencyjność w międzynarodowym i globalnym handlu technologiami, Warszawa-Łódź, PWN, 2001. 